\title{
Morphological identification and molecular confirmation of the deep-sea blue and red shrimp Aristeus antennatus larvae
}

\author{
Marta Carreton ${ }^{\text {Corresp.., }}{ }^{1}$ ， Joan B Company ${ }^{1}$, Laia Planella ${ }^{2}$, Sandra Heras ${ }^{2}$ ， José Luis García-Marín ${ }^{2}$, Melania \\ Agulló $^{2}$, Morane Clavel-Henry ${ }^{1}$, Guiomar Rotllant ${ }^{1}$, Antonina dos Santos ${ }^{3}$, María Inés Roldán ${ }^{2}$ \\ ${ }^{1}$ Institut de Ciències del Mar (ICM-CSIC), Consejo Superior de Investigaciones Científicas, Barcelona, Spain \\ 2 Laboratori d'Ictiologia Genètica, Universitat de Girona, Girona, Spain \\ 3 Instituto Português do Mar e da Atmosfera (IPMA), Lisboa, Portugal \\ Corresponding Author: Marta Carreton \\ Email address: mcarreton@icm.csic.es \\ The early life stages of the blue and red shrimp Aristeus antennatus (Decapoda: \\ Dendrobranchiata: Penaeoidea: Aristeidae) were described by Heldt in 1955 based on \\ plankton samples, larval rearing and assumptions of species habitat. Even with adequate \\ keys, identification of its first larval stages remained a difficult task due to the lack of \\ specific morphological characters which would differentiate them from other Penaeoidea \\ species. Larvae of $A$. antennatus were collected in the continental slope off the Spanish \\ Mediterranean coast in August 2016 with a neuston net and preserved in ethanol 96\%. \\ DNA from the larvae was extracted and the molecular markers COI and 16S rDNA were \\ sequenced and compared to that of adults with the objective of confirming the previous \\ morphological description. Then, we present additional information to the morphological \\ description of $A$. antennatus larval stages through scanning electron microscopy and \\ molecular analysis. This represents the first documented occurrence of $A$. antennatus \\ larvae off the Catalan coast and sets the grounds for further work on larval ecology and \\ population connectivity of the species, which is an important contribution to a more \\ sustainable fishery.
}


1 Morphological identification and molecular confirmation of the 2 deep-sea blue and red shrimp Aristeus antennatus larvae

3

4

5

6

7

8

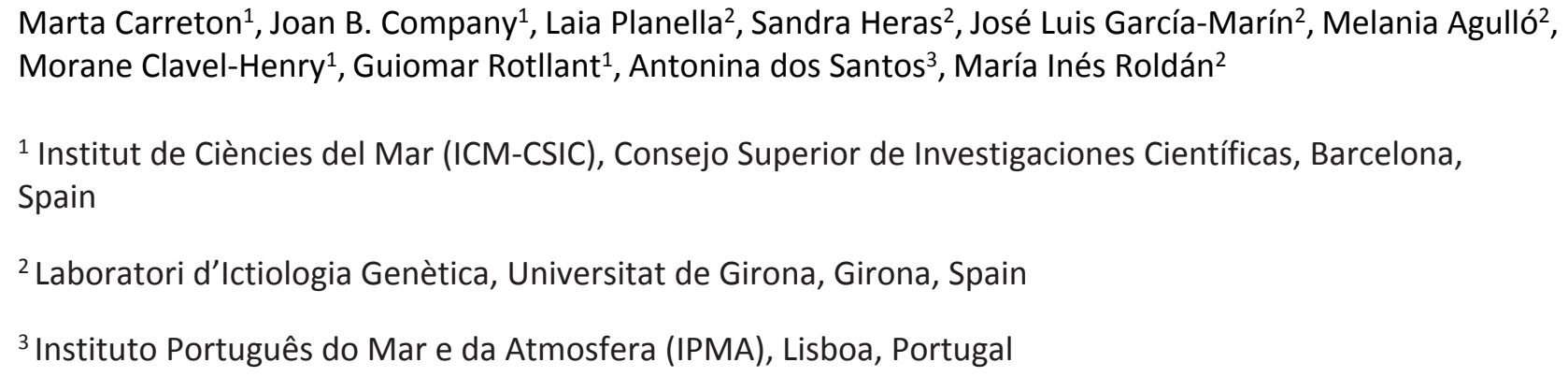

Corresponding Author:

Marta Carreton ${ }^{1}$

Passeig Marítim de la Barceloneta 37-49, Barcelona, 08003, Spain

Email address: $\underline{\text { mcarreton@icm.csic.es }}$

\begin{abstract}
The early life stages of the blue and red shrimp Aristeus antennatus (Decapoda: Dendrobranchiata: Penaeoidea: Aristeidae) were described by Heldt in 1955 based on plankton samples, larval rearing and assumptions of species habitat. Even with adequate keys, identification of its first larval stages remained a difficult task due to the lack of specific morphological characters which would differentiate them from other Penaeoidea species. Larvae of $A$. antennatus were collected in the continental slope off the Spanish Mediterranean coast in August 2016 with a neuston net and preserved in ethanol 96\%. DNA from the larvae was extracted and the molecular markers COI and 16S rDNA were sequenced and compared to that of adults with the objective of confirming the previous morphological description. Then, we present additional information to the morphological description of $A$. antennatus larval stages through scanning electron microscopy and molecular analysis. This represents the first documented occurrence of $A$. antennatus larvae off the Catalan coast and sets the grounds for further work on larval ecology and population connectivity of the species, which is an important contribution to a more sustainable fishery.
\end{abstract}


31

32

33

34

35

36

37

38

39

40

41

42

43

44

45

46

47

48

49

50

51

52

53

54

55

56

57

58

59

60

61

62

63

64

65

66

67

68

69

70

71

72

73

74

75

\section{Introduction}

The deep-sea blue and red shrimp Aristeus antennatus (RISSO 1816; Decapoda: Dendrobranchiata: Penaeoidea: Aristeidae) is one of the most valuable fishing resources in the Mediterranean Sea. It is the main target of bottom trawlers along the coasts of Northwestern Africa, Portugal, Spain, France, Italy and Malta (www.fao.org). In the Spanish Mediterranean coast, it can represent up to 50\% of the economical benefits for the fishermen associations (MAYNOU 2008, DGPAM 2017). Mature females aggregate at the continental shelf break in the summer (SARDÀ et al. 1994, 1997). Despite its social and economic relevance in the area, the knowledge about the species' life cycle remains incomplete as its larval stages are still scarcely known. As this fishery progresses towards more integrative methods of stock assessment and management, filling the knowledge gap about the early life stages of $A$. antennatus is a crucial step in the study of its dispersal and population connectivity. In dendrobranchiate shrimps, the first larval stage hatching from the egg is usually a free-living nauplius. This stage has up to 6 substages depending on the species. It is followed by a variable number of zoeal stages often referred to as protozoea (early zoeae, with natatory antennules and antennae) and mysis (late zoeae, where the natatory function is assured by the pereiopods). The last mysis then metamorphoses into the first decapodid, which after a number of moults will come to settle in the adult habitat (ANGER 2001).

The description of the larval stages of A. antennatus (HELDT 1955) was based on 35 individuals caught in a plankton survey around the Balearic archipelago. The assumptions leading to the attribution of the larvae to A. antennatus were based on the author's extensive knowledge of Penaeoid larvae in the Mediterranean Sea. This morphological identification has never been confirmed since. To present date, occurrence of A. antennatus larvae has only been detected in low numbers in plankton surveys off the Algerian and Portuguese Atlantic coasts, the Canary Islands and in the Balearic Sea, identified using Heldt's larval descriptions (SERIDJI 1971; DOS SANTOS, 1998, CARBONELl et al. 2010, LANDEIRA 2010, TORRES et al. 2013). The morphological description of a second mysis stage (TORRES et al. 2013), also based on larvae caught in plankton, was the most recent addition to the larval series, with the last larval stages still remaining unknown. Rearing of larvae in the laboratory from berried females is a usual technique to accomplish the description of a complete larval cycle (e.g. Di MUZIO et al. 2018). This is not possible in the case of A. antennatus due to the particularity of dendrobranchiate shrimps releasing their eggs directly to the water column, as opposed to being carried by females. To our knowledge, only one deep-sea Penaeoid larva from a plankton survey has been molecularly identified (BRACKEN-GRISSOM et al. 2012). The available descriptions of Penaeoid larvae from laboratory studies correspond only to species inhabiting shallow waters - as for instance the caramote prawn Penaeus kerathurus (TORKMEN 2003) - since females are easily cultured in tanks and eggs can be collected from the water upon release. No study has yet reported the culture of females of any deep-sea Penaeoid species. The morphological identification of Penaeoidea first larval stage, the protozoea I (PZI), is often a particularly difficult task due not only to the small size of the specimens but also to the fact that in some cases different species share the same larval morphology (MARTIN et al. 2014). It is only in later stages that the different larval series can be more easily distinguished based on morphological traits visible at the optical stereomicroscope, such as the presence and number of rostrum spines, supraorbital and/or pterygostomian spines, etc. On this matter, the early larval stages of $A$. antennatus are no exception. In fact, the description of the PZI was based on a single individual captured in the plankton of Balearic waters, in the Western Mediterranean Sea (HELDT 1955). The morphological characters that distinguish A. antennatus PZI from other Penaeoid species present in 
76

77

78

79

80

81

82

83

84

85

86

87

88

89

90

91

92

93

94

95

96

97

98

99

100

101

102

103

104

105

106

107

108

109

110

111

112

113

114

115

116

117

118

119

120

121

our study area such as Sicyonia carinata, Parapenaeus longirostris or Funchalia woodwardii are generally clear (DOS SANTOS \& LINDLEY 2001). However, the distinction between Aristeidae and Benthesicymidae PZI stage is more difficult because the only morphological character that allows their differentiation is a small endopod on the third maxilliped (mxp3), present in A. antennatus and absent in Gennadas spp. (HELDT 1955, GURNEY 1924). In the case of A. antennatus, the mxp3 is birramous, with 2 long plumose setae and 1 small simple seta on the exopod. In the case of Gennadas spp., the mxp3 is unirramous with 2 long plumose terminal setae. The reproductive period of the genus Gennadas has not yet been studied, but larvae caught in the plankton all year round have been classified as Gennadas spp. according to available information (FUSTÉ 1982, 1987; TORRES et al. 2014). The reproductive period of $A$. antennatus in the Mediterranean Sea is strictly seasonal in the summer (COMPANY et al. 2003). With both larval types occurring concurrently during the summer, their morphological differentiation becomes a key issue in the study of decapod larval communities and of $A$. antennatus larval distribution in particular.

The available descriptions of penaeoid larvae from plankton surveys have generally based their identification on an extensive knowledge of the adult morphology and ecology (HELDT 1938, 1955, GURNEY 1924). Although morphological identification is an essential first step, in some cases it can be insufficient and lead to misidentifications (PALERO et al. 2008, SUlLIVAN \& NEIGEL 2017). In this context, the use of molecular markers can be particularly useful in the confirmation of visual identification of specimens, in complement to keys and descriptions based on morphological characters (OLSON et al. 1991, WEBB et al. 2006). Previous studies on decapod crustacean larvae have used this technique either to confirm existing descriptions or as a complement to the descriptions of new stages (RAUPACH \& RADULOVICI 2015, LANDEIRA et al. 2014, BRACKENGRISSOM et al. 2012, PAN et al. 2008).

The objective of this study was to examine the morphology of the first protozoea of the deep-sea blue and red shrimp A. antennatus in order to find useful characters to distinguish it from Gennadas spp. larvae and to use molecular techniques to confirm the identification of all its known larval stages.

\section{Materials and methods}

\subsection{Sampling and morphological identification of $A$. antennatus and Gennadas spp. larvae and adult specimens}

In order to obtain both $A$. antennatus and Gennadas spp. larval types, we performed 2 plankton samplings, one in the summer when $A$. antennatus is at its peak reproductive period, and one in the winter, when $A$. antennatus does not reproduce but Gennadas spp. larvae are likely to be found. Nevertheless, the presence of Gennadas spp. larvae has been reported in the summer in the Balearic Sea (TORRES et al. 2014) and we were aware that we could encounter a mix of both species when aiming to collect $A$. antennatus PZI larvae in the summer. Summer sampling took place during a deep-sea cruise from mid-July to the end of August 2016 on board the research vessel García del Cid in various locations off the Spanish Mediterranean coast (Fig. 1). Plankton samples were taken using a $0.5 \mathrm{~m}^{2}$-mouth neuston net with a $300-\mu \mathrm{m}$ mesh between 0.5 and $1 \mathrm{~m}$ depth over bottoms of 123 to $1626 \mathrm{~m}$. The samples were rinsed with distilled water and preserved in 96\% ethanol. Samples were sorted in the laboratory using a Leica Wild M6 stereomicroscope and all larvae morphologically identified as A. antennatus following the available 
122 descriptions (HELDT 1955, TORRES et al. 2013) were stored individually in 96\% ethanol.

123 Winter sampling took place from mid-February to early March 2017 during a deep-sea cruise on

124 board the same research vessel off the NW Mediterranean coast (Fig. 1). Plankton samples were

125 taken in integrated oblique tows using a $60-\mathrm{cm}$ diameter bongo with a $300-\mu \mathrm{m}$ mesh net between

$126500 \mathrm{~m}$ depth and the surface, over bottoms of 1952 and $1790 \mathrm{~m}$. They were sorted on board using an

127 Olympus SZ stereomicroscope and larvae morphologically identified as Gennadas spp. PZ I

128 following the available description (GURNEY 1924) were rinsed with distilled water and preserved

129 individually in $96 \%$ ethanol.

130 Identifications of larvae through DNA barcoding are only reliable when the obtained sequences are

131 compared to those of adult specimens of known species. Adults of A. antennatus from commercial

132 trawling vessels had been previously identified and cross-checked with the available literature

133 (ZARIQUIEY-ÁLVAREZ 1968). They had been collected, preserved and their DNA amplified and the

134 resulting sequences were therefore available for comparison. The GenBank accession numbers are

135 EU977139-40 for 16S rDNA (SARDÀ et al. 2010) and EU908514 for COI (RoLDÁN et al. 2009). In

136 the case of Gennadas elegans, two adult individuals were selected from a sampling cruise in May

1372010 in the Mediterranean Sea. They had been previously identified by Dr. Pere Abelló at the

138 Institut de Ciències del Mar according to the available literature (ZARIQUIEY-ÁLVAREZ 1968) and

139 preserved in $96 \%$ ethanol. For the purpose of this paper, we extracted DNA from their abdominal

140 tissue and sequenced the product following the same method as for Gennadas spp. larvae to provide genetic information about the species (GenBank accession numbers MH605176 and MH605177).

\subsection{Analysis of the protozoea I pool}

\subsubsection{Morphological analysis}

In order to closely examine the morphology of the PZI larvae from the summer sampling, Scanning Electron Microscopy was used for 10 randomly selected individuals identified as A. antennatus PZI. Also, 3 individuals from the winter sampling, morphologically identified as Gennadas spp. PZI, were randomly selected. Both sets of larvae were immersed in a graded acetone series $(25,50,75$ and $100 \%$ ), dried to critical point, mounted on stubs with self-adhesive carbon stickers and coated in gold. They were observed under a Hitachi S-3500N scanning electron microscope.

Furthermore, measurements of carapace length, telson rami length, telson angle and length of last somite of pleon were taken for all remaining individuals from the winter sampling identified as Gennadas spp. $(\mathrm{n}=9)$. Also, the same measurements were carried out for 10 individuals from the summer sampling, identified as A. antennatus. To do this, we used a Leica M205 C stereomicroscope and ImageJ image analysis software.

\subsubsection{Molecular analysis}

In order to confirm the identity of a representative sample of the protozoea I pool found in the summer sampling, we randomly selected $24 \mathrm{PZI}$ individuals attributed to A. antennatus, from a total of 527 found. Selection was done according to spatial criteria with the objective of covering the whole study area. A maximum of 3 larvae per station were selected where the total number found was highest. We also randomly selected 4 PZI larvae from the winter sampling, morphologically attributed to Gennadas spp., from a total of 11 individuals found. Information about larvae analyzed and their GenBank accession numbers are shown in Table 1.

167 DNA isolations were carried out using a commercial kit optimized for small samples (Quick-DNA 
168 Microprep Plus kit, Zymo Research) and resuspended in a final volume of $10 \mu \mathrm{L}$. A negative 169 control that contained no sample was included in every isolation round to check for contamination 170 during the experiments.

171 For larvae morphologically identified as A. antennatus, a 617-base pair fragment of the 172 mitochondrial gene Cytochrome Oxidase I (COI) was amplified by polymerase chain reaction 173 (PCR) using the primer pair COILAa (5' GGT GAC CCA GTC CTT TAC CA 3') and COIHAa (5 174 GTC TGG ATA ATC AGA ATA CCG AC 3) (RoLDÁN et al. 2009), specific for A. antennatus. For 175 larvae and adult individuals identified as Gennadas spp., a 658-base pair fragment of the COI gene 176 was amplified using the primer pair CrustDF1 (5' GGT CWA CAA AYC ATA AAG AYA TTG G 177 3') (STEINKE et al. 2016) and HCO-2198 (5' TAA ACT TCA GGG TGA CCA AAA AAT CA 3') 178 (FoLMER et al. 1994). PCRs were carried out in a final volume of $25 \mu \mathrm{L}$, containing $12.50 \mu \mathrm{L}$ of 179 Supreme NZYTaq Green PCR Master Mix (NZYTech), $0.5 \mu \mathrm{M}$ of each primer, $2.5 \mu \mathrm{L}$ of the 180 template DNA solution, and PCR-grade water up to $25 \mu \mathrm{L}$. The thermal cycling conditions were as follows: an initial denaturation step at $95{ }^{\circ} \mathrm{C}$ for $5 \mathrm{~min}$, followed by 35 cycles of denaturation at 95 ${ }^{\circ} \mathrm{C}$ for $30 \mathrm{~s}$; annealing at $53{ }^{\circ} \mathrm{C}$ (COILAa and COIHAa) or at $49{ }^{\circ} \mathrm{C}$ (CrustDF1 and HCO-2198) for $30 \mathrm{~s}$; extension at $72{ }^{\circ} \mathrm{C}$ for $45 \mathrm{~s}$; and a final extension step at $72{ }^{\circ} \mathrm{C}$ for $5 \mathrm{~min}$. A negative control that contained no DNA was included in every PCR round to check for cross-contamination.

185 PCR products were run on a $1 \%$ agarose gel stained with Real Safe (Durviz) and imaged under UV light, to verify amplicon size. PCR products were bidirectionally sequenced using the PCR primers. Electropherogram analysis and overlapping was conducted in Geneious 8.1.8 (Biomatters Ltd.). During electropherogram analysis, the primer annealing regions and the low quality regions at both ends of each electropherogram were trimmed (error probability limit of 0.03 ). Sequence reads were manually checked for sequencing errors or ambiguous base calls. The positions with double peaks were coded using the IUPAC ambiguity code (e.g., R: G or A). In order to check for possible pseudogenes, the sequences were aligned with BioEdit and no insertions or deletions were detected. Then, all sequences were translated into proteins with online software ExPASY (GASTEIGER et al. 2003) and no stop codons were detected in the appropriate reading frame. The resulting nucleotide sequences were compared to available information in GenBank using Basic Local Alignment Search Tool (BLASTN 2.8.0, ZHANG Z. et al. 2000).

\subsection{Analysis of all known larval stages of $A$. antennatus}

For the molecular confirmation of the rest of known larval stages of $A$. antennatus, we randomly selected 3 PZII, 1 PZIII, 3 mysis I (MI) and 1 mysis II (MII) and followed the same procedure as in section 2.2.1 (Table 2).

In addition, a molecular analysis with ribosomal gene 16S rDNA was conducted for all known larval stages. To do this, we randomly selected 5 PZI, 6 PZII, 5 PZIII, 6 MI and 2 MII (Table 2). Genomic DNA isolation from whole larvae (HotSHOT) was performed following MONTERO-PAU et al. (2008) with slight modifications. Polymerase chain reaction (PCR; SAIKI et al. 1988) methods for amplification of the mitochondrial 16S rDNA gene followed the procedures outlined in ROLDÁN et al. (2009). Standard precautions were adopted to detect contamination and related problems. PCR products were verified on $1 \%$ agarose gel with ethidium bromide $(0.5 \mathrm{mg} / \mathrm{ml})$ and were purified for sequencing by treating with exonuclease I and shrimp alkaline phosphatase (WERLE et al. 1994). DNA sequencing reactions were carried out with BigDye Terminator v3.1 Cycle Sequencing Kit (Applied Biosystems) according to the manufacturer's instructions. Primers used for sequencing were the same as those employed for PCR amplifications. Finally, labelled fragments were loaded 
onto an ABI PRISM 3130 Genetic Analyzer (Applied Biosystems) at the Laboratori d'Ictiologia

215 Genètica, Universitat de Girona, Spain.

216 Nucleotide sequences were aligned and edited in Geneious v7.1.4 (KEARSE et al. 2012). In order to

217 confirm the identification of the larvae, simultaneous comparisons were done with reference

218 sequences from adults of six species of dendrobranchiate decapod crustaceans: Aristeus antennatus, Aristaeomorpha foliacea, Genadas elegans, Gennadas valens, Parapenaeus longirostris and Penaeus (Melicertus) kerathurus. The corresponding GenBank accession numbers are: EU97713940 (SARDÀ et al. 2010), MF496984-86 (ROLDÁN et al. 2017), JX403858.1 (BRACKEN-GRISSOM et al. 2012), KU324845.1 (ZiTARI-ChiATti et al. 2009) and EF589715.1 (PASCOAL et al. 2008) respectively.

\section{Results}

\subsection{Analysis of the protozoea I pool}

\subsubsection{Morphological analyses}

The morphology of the third maxilliped (mxp3) of the PZI larvae selected was studied under SEM. For the summer larvae examined (expected to be A. antennatus), the mxp3 was not visible in 2 of the 10 selected individuals due to the specimens' position. In the other eight, the mxp3 was clearly birramous and showed 2 long plumose setae on the exopod (Fig. 2). No small simple seta was observed on the exopod of the mxp3 in any of the individuals. For the winter larvae examined (then designed as Gennadas spp. since A. antennatus only reproduces in summer), the mxp3 was clearly visible in 2 of the 3 individuals and it was birramous in both of them (Fig. 3). The endopod in Gennadas spp. is smaller and less conspicuous than that of A. antennatus, but differences among individuals do not allow the use of this character for its taxonomical identification. Other morphological characters were observed under SEM, such as the presence of frontal organs and the telson angle, with no conclusive distinctive traits between both species. A comparison of all morphological characters observed is presented in Table 3.

\subsubsection{Molecular analyses}

The COI sequences from the 24 PZI larvae from the summer sampling revealed 8 different haplotypes and all retrieved only A. antennatus sequences when analyzed in BLAST (GenBank accession numbers MH605140 to MH605163). To our knowledge, this is the first record of $A$. antennatus PZI stage since its description from a single individual (HELDT 1955). On the other hand, all 4 larvae morphologically identified as Gennadas spp. from the larval description showed an average resemblance of $99.38 \%$ to the sequences from the 2 Gennadas elegans adult individuals analyzed (GenBank accession numbers MH605172 to MH605175 for larvae; MH605176 and MH605177 for adults).

\subsection{Molecular analysis of all known larval stages of $A$. antennatus}

All known stages of $A$. antennatus were genetically identified with two markers: $\mathrm{COI}$ and $16 \mathrm{~S}$ rDNA (Table 2). For marker COI, all 8 larvae analyzed corresponding to the four remaining known larval stages of $A$. antennatus were successfully sequenced (617 bp) and were identified as $A$. antennatus. The sequences corresponded to 2 different haplotypes (GenBank accession numbers 
260 MH605164 to MH605171). For marker 16S rDNA, all 24 larvae analyzed from the five known 261 larval stages of the species were successfully sequenced (300 bp) and all were also undoubtedly 262 identified as $A$. antennatus. The sequences corresponded to 4 different haplotypes (GenBank

\section{Discussion}

The larvae collected in the present study are the highest number of $A$. antennatus larvae ever found in plankton samples, and analysis of these data (under preparation) could shed light on the species' larval distribution and connectivity for the Western Mediterranean Sea. All collected larval stages of A. antennatus were identified with the available morphological descriptions made by HELDT (1955) and TORRES et al. (2013) and confirmed by molecular methods.

From a morphological point of view, there are still some difficulties in identifying the first prozoea of $A$. antennatus, since this stage is strikingly similar to that of Gennadas spp. In this study, even using SEM it was not possible to confirm the previous description of these two species. The available description for the first prozoea of Gennadas spp. (GURNEY 1924) notes an unirramous third maxilliped, whereas in our case two of the three G. elegans PZI showed a small endopod on the mxp3. The presence of a birramous mxp3 in G. elegans PZI stage may eliminate the possibility of distinguishing it from A. antennatus using morphological characters. The examination of other morphological traits such as telson invagination and anal spines structure did not yield any concluding results on features to differentiate both species despite the slight differences noted. On the other hand, the observed A. antennatus PZI larvae invariably showed only 2 long plumose setae on the exopod of the mxp3. The description appointed, in addition, one small simple seta on the exopod of the mxp3 (HELDT 1955), which was not observed in any of the individuals examined. This suggests that the small simple seta described may appear later in the development of this stage and that newly molted PZI of $A$. antennatus would only present the 2 long plumose setae. Nevertheless, we have examined all 527 A. antennatus PZI individuals collected and all of them show only the 2 long plumose setae on the exopod of the mxp3 when observed at the stereomicroscope. The presence of a small simple seta on the exopod of the mxp3 is often used as a distinctive character of $A$. antennatus PZI when the endopod is not clearly visible. However, in the light of our results we recommend that this feature not be used to distinguish the PZI of $A$. antennatus and G. elegans.

Our results show that $100 \%$ of the analyzed PZI larvae with the shared morphology of $A$. antennatus/Gennadas spp. were molecularly identified as A. antennatus. Nevertheless, the presence of Gennadas spp. older larval stages in this sampling collection (CARRETón et al. unpubl. data) calls for caution during morphological identification. Until a new and standardized description of both larval types is completed and a morphological character is found to tell both species apart, molecular techniques remain the most reliable method for a correct species identification. According to the descriptions of HELDT (1995), the larval series of $A$. antennatus is also morphologically very similar to that of Aristaeomorpha foliacea (RISSO 1827). Both species keep a smooth abdomen and carapace throughout their larval cycle, and it is possible that their PZIs can be confused as well in areas where both species coexist abundantly (Central and Eastern Mediterranean). Unfortunately, there is still no available description of the PZI of $A$. foliacea that 
306

307

308

309

310

311

312

313

314

315

316

317

318

319

320

321

322

323

324

325

326

327

328

329

330

331

332

333

334

335

336

337

338

339

340

341

342

343

344

345

346

347

348

349

350

351

we can use to clarify this matter. In our study area, records of $A$. foliacea adult individuals have been decreasing and the species has been considered locally extinct in the Northwestern Mediterranean (CAU et al. 2002, CARTES et al. 2011). Nevertheless, a more thorough examination of the available bibliography is being carried out to clarify the morphological differences among these larval forms in the hopes of facilitating a more accurate identification (CARRETÓN et al., in prep).

\section{Conclusions}

Molecular analysis performed for all known larval stages of $A$. antennatus caught in the Western Mediterranean Sea proved that available descriptions for $A$. antennatus larval series are accurate. Molecular tools used clearly differentiate PZI of $A$. antennatus and Gennadas elegans. From the morphological examination of the first protozoea stage, and contrary of what was expected, the third maxilliped is similar for both A. antennatus and Gennadas elegans, which makes this character not suitable for use in morphological identification.

The absence of a small simple seta on the exopod of the third maxilliped of $A$. antennatus first protozoeae examined indicates that this character is not suitable for use in the morphological differentiation of $A$. antennatus and Gennadas elegans first protozoea.

\section{Acknowledgements}

The authors would like to thank Dr. Pere Abelló for providing and identifying the G. elegans adult individuals used in this study. Thanks to José Manuel Fortuño for his dedication and expertise during the SEM sessions. Molecular analyses of COI region were performed at AllGenetics (A Coruña, Spain).

\section{References}

Bracken-Grissom, H.D., Felder, D.L., Volmer, N., Martin, J. And K.A. Crandall. 2012. Phylogenetics Links Monster Larva to Deep-Sea Shrimp. - Ecology and Evolution 2(10): $2367-$ 2373.

Cau A., Carbonell A., Follesa M.C., Norrito G., Orsi-Relini L., Ragonese S., Rinelli P. 2002. MEDITS-based information on the deep-water red shrimps Aristaeomorpha foliacea and Aristeus antennatus (Crustacea: Decapoda: Aristeidae). - Scientia Marina 66: 103-124.

Carbonell A., Dos Santos A., Alemany F., Vélez-Belchi P. 2010. Larvae of the red shrimp Aristeus antennatus (Decapoda: Dendrobranchiata: Aristeidae) in the Balearic Sea: new occurrences fifty years later. - Marine Biodiversity Records 3: 1-4.

CARTES J.E., MAYNOU F., FANELli E. 2011. Nile damming as plausible cause of extinction and drop in abundance of deep-sea shrimp in the western Mediterranean over broad spatial scales. Progress in Oceanography 91(3): 286-294.

Company J.B., SARdÀ F., Puig, P., CARTes J.E., PAlanques A. 2003. Duration and timing of reproduction in decapod crustaceans of the NW Mediterranean continental margin: Is there a general pattern? - Marine Ecology Progress Series 261: 201-216.

DGPAM 2017. Departament d'Agricultura, Ramaderia, Pesca i Alimentació, Generalitat de Catalunya. Estadístiques de pesca. - URL

http://agricultura.gencat.cat/ca/ambits/pesca/dar_estadistiques_pesca_subhastada [accessed 06/04/2018] 
352 Di Muzio G., Basile R., Pessani D. 2018. Description of the zoeal stages of Periclimenes

353 aegylios Grippa \& d'Udekem d'Acoz, 1996 (Crustacea: Decapoda: Palaemonidae) reared in the

354 laboratory. - Zootaxa 4418(3).

355 Dos SANTOS A. 1998. On the occurrence of larvae of Parapenaeus longirostris (Crustacea:

356 Decapoda: Penaeoidea) off the Portuguese coast. - Journal of Natural History 32(10-11):

357 1519-1523.

358 Dos SANTOS A., LindLeY J.A. 2001. Crustacea Decapoda: Larvae II. Dendrobranchiata

359 (Aristeidae, Benthesicymidae, Penaeidae, Solenoceridae, Sicyonidae, Sergestidae, and

360 Luciferidae). - ICES Identification Leaflets for Plankton. International Council for the

361 Exploration of the Sea, Copenhagen. ISSN 1019-1097.

362 Folmer O., Black M., HoEH W., Lutz R., VRIJENHOEK R. 1994. DNA primers for amplification

363

364

365

366

367

368

369

370

371

372

373

374

375

376

377

378

379

380

381

382

383

384

385

386

387

388

389

390

391

392

393

394

395

396

397 of mitochondrial cytochrome c oxidase subunit I from diverse metazoan invertebrates. Molecular Marine Biology and Biotechnology 3:294-299.

Fusté X. 1982. Ciclo anual de las larvas de Crustáceos Decápodos de la costa de Barcelona.Investigación Pesquera 46(2):287-303.

Fusté X. 1987. Distribución de larvas de Crustáceos Decápodos de la costa de Cataluña. Investigación Pesquera 51(1): 277-284.

Gasteiger E., Gattiker A., Hoogland C., IVAnyi I., ApPel R.D., BAiroch A. 2003. ExPASy: the proteomics server for in-depth protein knowledge and analysis. Nucleic Acids Research 31:3784-3788.

GuRNEY R. 1924. Decapod larvae. Part IX. British Antarctic (Terra Nova) Expedition. - Natural History Reports Terra Nova Expedition 8(2): 38-200.

HeldT, J. H. 1938. La réproduction chez les Crustacés Décapodes de la famille des Pénéides. Annales de l'Institut Océanographique de Monaco 18(2): 31-206

HELDT J.H. 1955. Contribution à l'étude de la biologie des crevettes pénéides Aristeomorpha

foliacea (Risso) et Aristeus antennatus (Risso) (formes larvaires). - Bulletins de la Société des Sciences Naturelles de Tunisie VIII(1-2): 1-29.

Kearse M., Moir R., Wilson A., Stones-Havas S., Cheung M., Sturrock S., Buxton S., Cooper A., Markowitz S., Duran C., Thierer T., Ashton B., Mentues P., Drummond A. 2012. Geneious Basic: an integrated and extendable desktop software platform for the organization and analysis of sequence data. - Bioinformatics 28: 1647-1649.

LANDEIRA J.M. 2010. Larvas planctónicas de crustáceos decápodos en las Islas Canarias. PhD Thesis. - Universidad de La Laguna (Spain).

Landeira J.M., Chan T.Y., Aguilar-Soto N., Jiang G.C., Yang C.H. 2014. Description of the decapodid stage of Plesionika narval (fabricius, 1787) (decapoda: Caridea: Pandalidæ) identified by DNA barcoding. - Journal of Crustacean Biology 34(3): 377-387.

Martin J.W., Olesen, J., HoEg, J.T. (ED.) 2014. Atlas of crustacean larvae. - Johns Hopkins University Press. ISBN: 978-1421411972.

MAYNOU F. 2008. Environmental causes of the fluctuations of red shrimp (Aristeus antennatus) landings in the Catalan Sea. - Journal of Marine Systems 71: 294-302.

Montero-PAu J., Gómez A., MuÑoz J. 2008. Application of an inexpensive and highthroughput genomic DNA extraction method for the molecular ecology of zooplanktonic diapausing eggs. - Limnology and Oceanography: Methods 6: 218-222.

OlsON R.R., RunStAdLER J.A., KochER T. D. 1991. Whose larvae? - Nature 351: 357-358. Palero F., Guerao G., ABelló P. 2008. Morphology of the final stage phyllosoma larva of Scyllarus pygmaeus (Crustacea: Decapoda: Scyllaridae), identified by DNA analysis. - Journal 
400

401

402

403

404

405

406

407

408

409

410

411

412

413

414

415

416

417

418

419

420

421

422

423

424

425

426

427

428

429

430

431

432

433

434

435

436

437

438

439

440

441

442

443

of Plankton Research 30(4):483-488.

Pascoal A., Barros-Velazquez J., CePeda A., Gallardo J.M., Calo-Mata P. 2008.A polymerase chain reaction-restriction fragment length polymorphism method based on the analysis of a $16 \mathrm{~S}$ rRNA/tRNA(Val) mitochondrial region for species identification of commercial penaeid shrimps (Crustacea: Decapoda: Penaeoidea) of food interest. Electrophoresis 29(2): 499-509.

Pan M., McBeath A.J.A., Hay S.J., Pierce G.J., Cunningham C.O. 2008. Real-time PCR assay for detection and relative quantification of Liocarcinus depurator larvae from plankton samples. - Marine Biology 153(5): 859-870.

RAUPACH M.J., RADULOVICI A.E. 2015. Looking back on a decade of barcoding crustaceans. ZooKeys 539: 53-81.

RoldÁn M.I., HeRas S., PATELlani R., Maltagliati F. 2009. Analysis of genetic structure of the red shrimp Aristeus antennatus from the Western Mediterranean employing two mitochondrial regions. - Genetica 136(1): 1-4.

RoldÁn M.I., Heras S., Planella L., Agulló M., García Marín J.L. 2017. Easy genetic differentiation between sympatric crustacean decapods. - TCS, P-052.

Saiki R.K., Gelfand D.H., Stoffel S., Scharf S.J., Higuchi R., Horn G.T., Mullis K.B., ERLICH H.A. 1988. Primer-directed enzymatic amplification of DNA with a thermostable DNA polymerase. - Science 239: 487-491.

SARDÀ F., CARTES J.E., NORBIS W. 1994. Spatio-temporal structure of the deep-water shrimp Aristeus antennatus (Decapoda: Aristeidae) population in the western Mediterranean. - Fishery Bulletin 92: 599-607.

SARDÀ F., MAYNOU F., TALLÓ L. 1997. Seasonal and spatial mobility patterns of rose shrimp Aristeus antennatus in the Western Mediterranean: results of a long-term study. - Marine Ecology Progress Series 159: 133-141.

SARDÀ F., ROLDÁN M.I., HeRAS S., MALTAGLiati M. 2010. Influence of the genetic structure of the red and blue shrimp, Aristeus antennatus (Risso, 1816) on the sustainability of a deepsea population along a depth gradient in the Western Mediterranean. - Sci Mar 74:569-575.

SERIDJI, R. 1971. Contribution à l'étude des larves de crustacés décapodes en baie d'Alger. Pelagos III(2).

Steinke D., Prosser S.W.J., Hebert P.D.N. 2016. DNA Barcoding of Marine Metazoans. In: Bourlat S. (EDS) - Marine Genomics. Methods in Molecular Biology 1452. Humana Press, New York, NY.

Sullivan T.J., Neigel J.E. 2017. Misidentification of megalopae as a potential source of error in studies of population genetics and ecology of the blue crab Callinectes sapidus. Marine Ecology Progress Series 565:95-111.

TORKMEN G. 2003. Larval Development of the Grooved Shrimp (Penaeus kerathurus Forskal, 1775) Under Laboratory Conditions. - Turkish Journal of Fisheries and Aquatic Sciences 3: 97-103.

Torres A. P., Dos Santos A., Alemany F., Massutí E. 2013. Larval stages of crustacean species of interest for conservation and fishing exploitation in the western Mediterranean. Scientia Marina 77(1): 149-160.

Torres A.P., Dos Santos A., Balbín R., Alemany F., Massutí E., Reglero P. 2014. Decapod crustacean larval communities in the Balearic Sea (western Mediterranean): Seasonal composition, horizontal and vertical distribution patterns. - Journal of Marine Systems 138: $112-126$. 
444 WebB K.E., Barnes D.K. A., Clark M.S., Bowden D.A. 2006. DNA barcoding: A molecular 445 tool to identify Antarctic marine larvae. - Deep-Sea Research Part II: Topical Studies in 446 Oceanography 53(8-10): 1053-1060.

447 Werle E., SChNeIder C., Renner M., VölKer M., FieHn W. 1994. Convenient single-step, one 448 tube purification of PCR products for direct sequencing. - Nucleic Acids Research 22: 43544494355.

450 ZARIQUIEY-ÁlvareZ, R. 1968. Crustáceos decápodos ibéricos. Investigación Pesquera 32:1451510.

452 Zhang Z., SchWARtZ S., WAGNER L. \& Miller W. 2000. A greedy algorithm for aligning DNA 453 sequences. - Journal of Computational Biology 7(1-2): 203-14.

454

455

456 
Figure 1

Stations where larvae were selected.

Red dots: summer sampling. Blue dots: winter sampling. Bathymetry is shown every $200 \mathrm{~m}$.

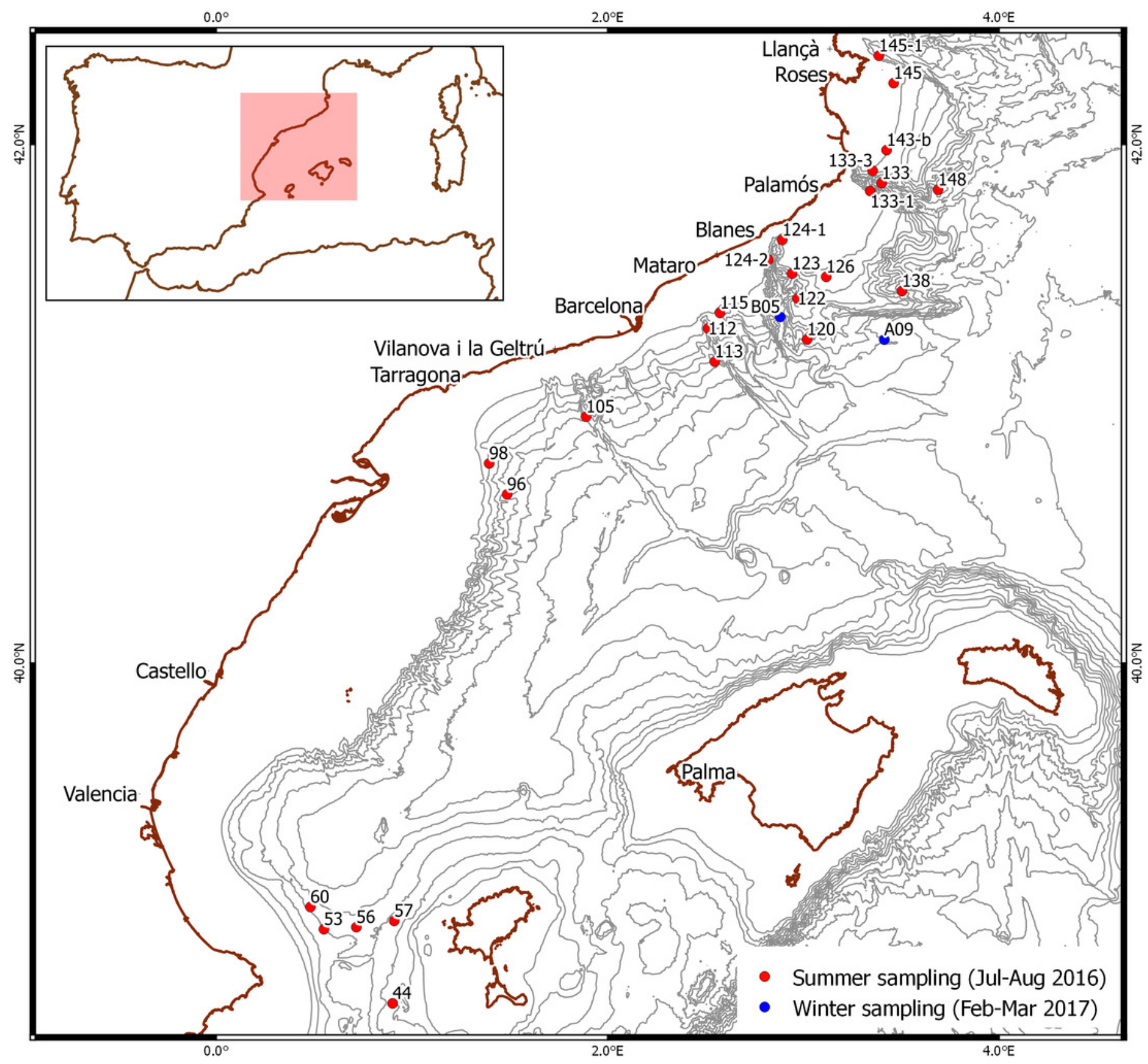




\section{Figure 2}

General view (A) and detail of a third maxilliped (B) of an Aristeus antennatus protozoea I.

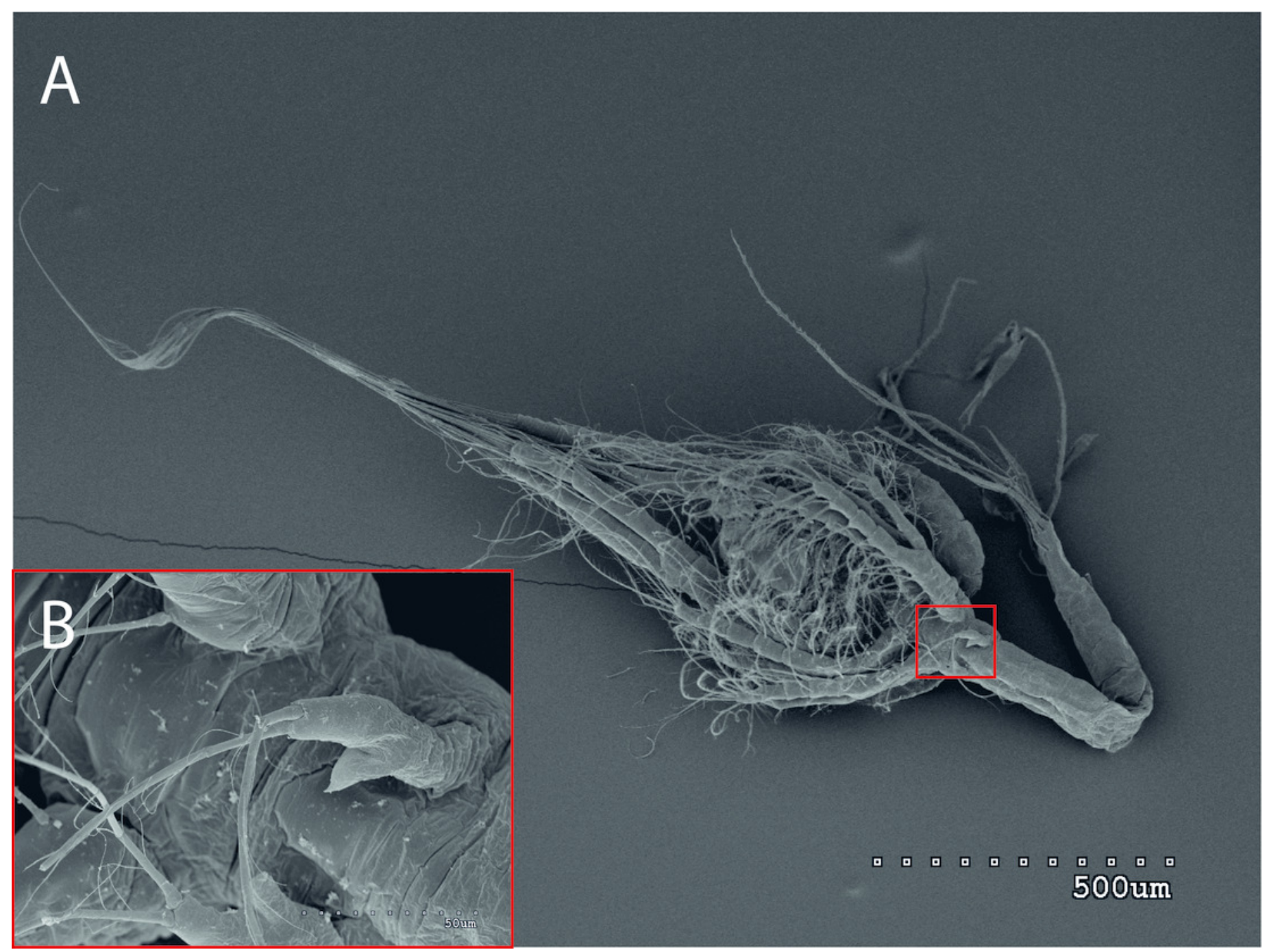


Figure 3

General view (A) and detail of a birramous third maxilliped (B) of a Gennadas elegans protozea I.

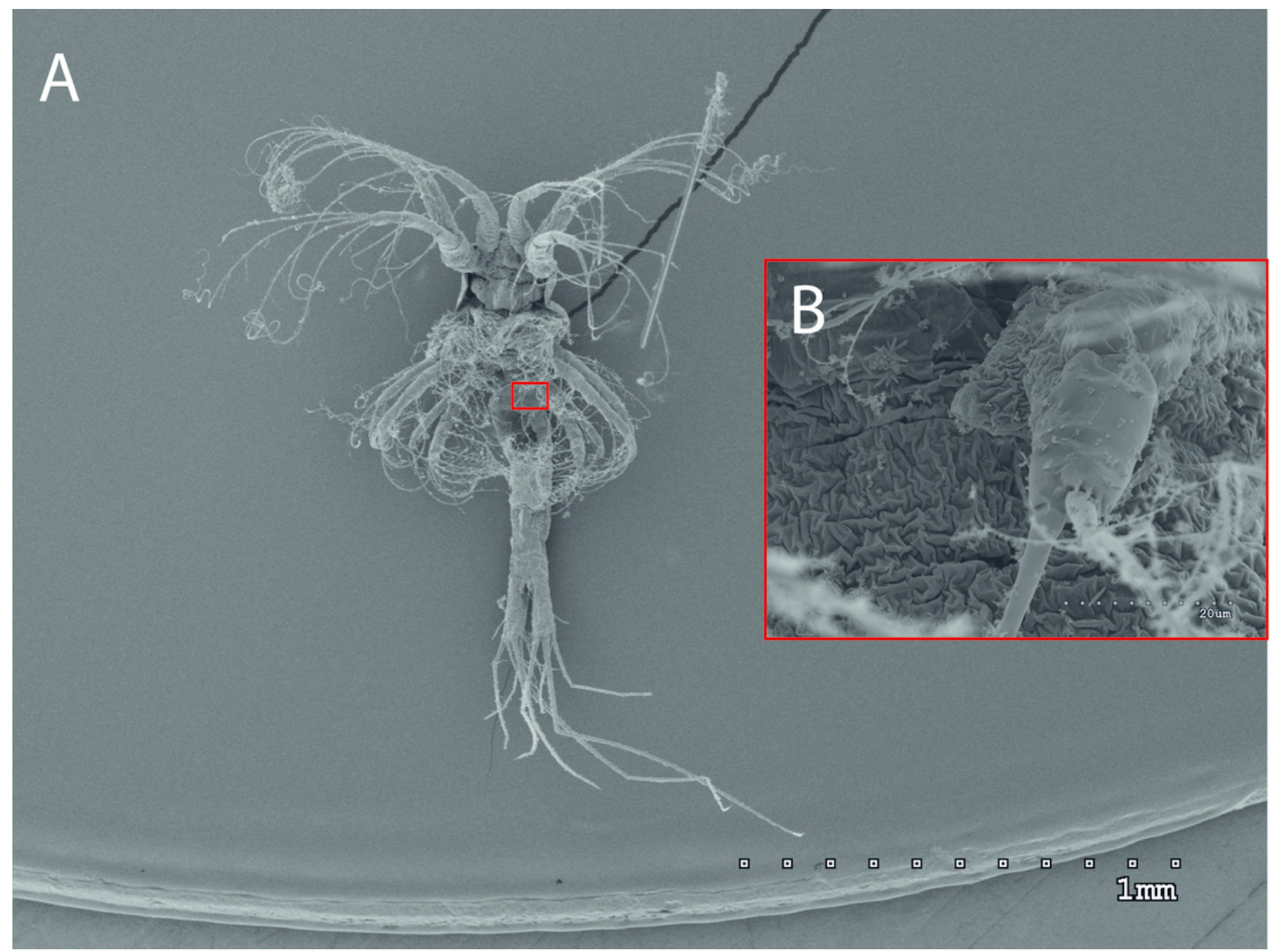




\section{Table 1 (on next page)}

List of protozoea I larvae analyzed by station.

PZ - protozoea. N - number of individuals analyzed. 


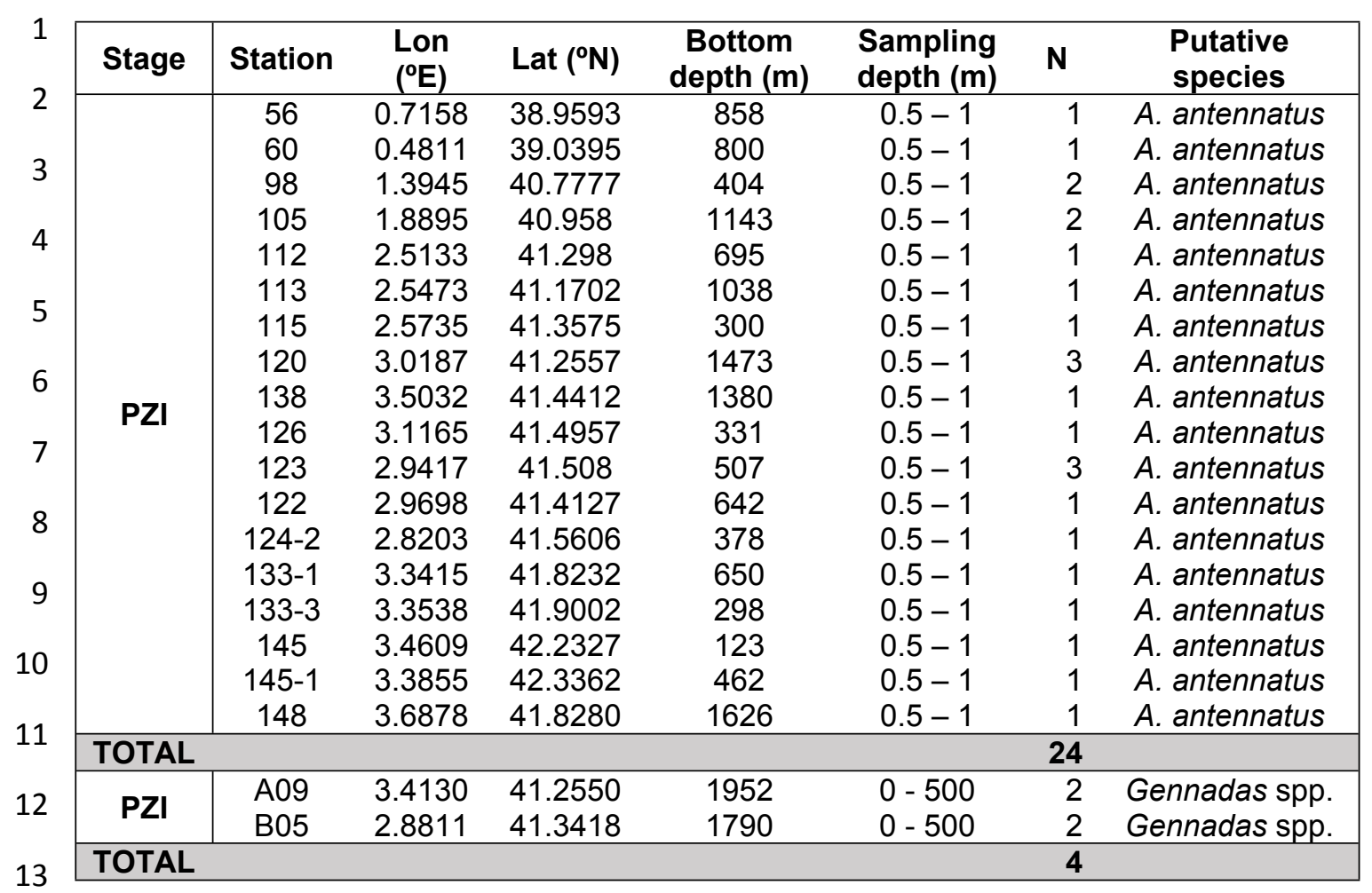

14

15

16

17 


\section{Table 2 (on next page)}

List of larvae analyzed for DNA regions COI (top) and 16S rDNA (bottom) by station.

Putative species is $\mathrm{A}$. antennatus in all cases. PZ - protozoea; $\mathrm{M}$ - mysis. $\mathrm{N}$ - number of individuals analyzed. 


\begin{tabular}{|c|c|c|c|c|c|c|c|}
\hline & Stage & Station & Lon $\left({ }^{\circ} \mathrm{E}\right)$ & Lat $\left({ }^{\circ} \mathrm{N}\right)$ & $\begin{array}{c}\text { Bottom } \\
\text { depth }(\mathrm{m})\end{array}$ & $\begin{array}{l}\text { Sampling } \\
\text { depth (m) }\end{array}$ & $\mathbf{N}$ \\
\hline \multirow{9}{*}{$\overline{\mathrm{O}}$} & PZI & & \multicolumn{5}{|c|}{ (see Table 1) } \\
\hline & \multirow{3}{*}{ PZII } & 96 & 1.4862 & 40.6578 & 940 & $0.5-1$ & 1 \\
\hline & & 138 & 3.5032 & 41.4412 & 1380 & $0.5-1$ & 1 \\
\hline & & 145 & 3.4609 & 42.2327 & 1626 & $0.5-1$ & 1 \\
\hline & PZIII & 57 & 0.9092 & 38.9843 & 728 & $0.5-1$ & 1 \\
\hline & \multirow{2}{*}{ MI } & 57 & 0.9092 & 38.9843 & 728 & $0.5-1$ & 2 \\
\hline & & 96 & 1.4862 & 40.6578 & 940 & $0.5-1$ & 1 \\
\hline & MII & 57 & 0.9092 & 38.9843 & 728 & $0.5-1$ & 1 \\
\hline & \multicolumn{2}{|l|}{ TOTAL } & & & & & 8 \\
\hline \multirow{13}{*}{ 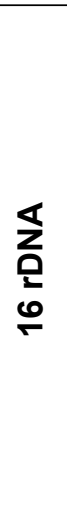 } & \multirow{2}{*}{ PZI } & 112 & 2.5133 & 41.298 & 695 & $0.5-1$ & 3 \\
\hline & & 113 & 2.5473 & 41.1702 & 1038 & $0.5-1$ & 2 \\
\hline & \multirow{4}{*}{ PZII } & $124-1$ & 2.8917 & 41.6367 & 200 & $0.5-1$ & 1 \\
\hline & & $143 b$ & 3.4248 & 41.9788 & 187 & $0.5-1$ & 2 \\
\hline & & 145 & 3.4609 & 42.2327 & 123 & $0.5-1$ & 1 \\
\hline & & 133 & 3.2760 & 41.8762 & 600 & $0.5-1$ & 2 \\
\hline & \multirow{2}{*}{ PZIII } & 57 & 0.9092 & 38.9843 & 728 & $0.5-1$ & 2 \\
\hline & & 44 & 0.9008 & 38.6558 & 528 & $0.5-1$ & 3 \\
\hline & \multirow{3}{*}{ MI } & 53 & 0.5502 & 38.9512 & 776 & $0.5-1$ & 1 \\
\hline & & 57 & 0.5502 & 38.9843 & 728 & $0.5-1$ & 1 \\
\hline & & 44 & 0.9008 & 38.6558 & 528 & $0.5-1$ & 4 \\
\hline & MII & 57 & 0.9092 & 38.9843 & 728 & $0.5-1$ & 2 \\
\hline & \multicolumn{2}{|l|}{ TOTAL } & & & & & 24 \\
\hline
\end{tabular}

1 


\section{Table 3(on next page)}

Comparison of relevant morphological characters of the first protozoea stage examined.

Mxp3 - third maxilliped. 
1

\begin{tabular}{|c|c|c|c|c|}
\hline $\begin{array}{l}\text { Morphological } \\
\text { characters }\end{array}$ & $\begin{array}{l}\text { Aristeus } \\
\text { antennatus } \\
\text { Heldt (1955) }\end{array}$ & $\begin{array}{l}\text { Aristeus } \\
\text { antennatus } \\
\text { Present study }\end{array}$ & $\begin{array}{l}\text { Gennadas sp. } \\
\text { Gurney (1924) }\end{array}$ & $\begin{array}{l}\text { Gennadas } \\
\text { elegans } \\
\text { Present study }\end{array}$ \\
\hline $\begin{array}{l}\text { Total length (TL; } \\
\mathrm{mm} \text { ) }\end{array}$ & 1.55 & $1.20 \pm 0.05$ & 0.98 & $1.10 \pm 0.10$ \\
\hline $\begin{array}{l}\text { Carapace length } \\
(\mathrm{CL} ; \mathrm{mm})\end{array}$ & NA & $0.42 \pm 0.03$ & NA & $0.38 \pm 0.04$ \\
\hline Mxp3 & birramous & birramous & unirramous & birramous \\
\hline $\begin{array}{l}\text { Number of setae } \\
\text { exop. Mxp3 }\end{array}$ & $\begin{array}{l}2 \text { long plumose, } \\
1 \text { small simple }\end{array}$ & 2 long plumose & 2 long plumose & 2 long plumose \\
\hline Frontal organs & small, round & small, round & small, round & small, round \\
\hline $\begin{array}{l}\text { Length of the } \\
\text { last somite of } \\
\text { the pleon with } \\
\text { telson }(\mathrm{mm})\end{array}$ & NA & $0.38 \pm 0.07$ & NA & $0.32 \pm 0.04$ \\
\hline $\begin{array}{l}\text { Length of the } \\
\text { telson rami } \\
(\mathrm{mm})\end{array}$ & NA & $0.11 \pm 0.01$ & NA & $0.11 \pm 0.02$ \\
\hline $\begin{array}{l}\text { Proportion: } \\
\text { length of last } \\
\text { somite of pleon } \\
\text { with telson / } \\
\text { length of telson } \\
\text { rami }\end{array}$ & NA & $0.30 \pm 0.5$ & NA & $0.35 \pm 0.05$ \\
\hline Telson angle $\left({ }^{\circ}\right)$ & NA & $35.73 \pm 8.32$ & NA & $35.84 \pm 7.67$ \\
\hline
\end{tabular}

